\title{
Indigenous Students In The Tertiary Education Sector
}

Susan Bandias, Charles Darwin University, Australia

Don Fuller, Charles Darwin University, Australia

Steven Larkin, Charles Darwin University, Australia

\begin{abstract}
Important recent objectives of indigenous education policy in Australia have been aimed at redressing indigenous economic and social disadvantage through increasing student retention, progression and completion rates in both compulsory and post-compulsory education. The two sectors of the tertiary education system, vocational education and training (VET) and higher education (HE), have usually been acknowledged as separate but crucial elements in Indigenous capacity building. The vocational education sector, in particular, has had an important role in equipping Indigenous people with the vocationally orientated skills required to participate in paid employment, the mainstream economy and the labour market (Dockery \& Milson, 2007).
\end{abstract}

Keywords: Indigenous; Vocational Education; Higher Education; Progression

\section{INTRODUCTION}

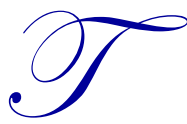

he pathways indigenous students take in their transition from post-compulsory education to paid employment, are multiple and varied. The vocational education and training (VET) sector in particular, has had an important role in equipping Indigenous people with the vocationally orientated skills required to participate in paid employment, the mainstream economy, and the labour market (Dockery \& Milson, 2007). However, research indicates that only a small proportion of Indigenous students access and complete post-compulsory education (Alford \& James, 2007; Bradley et al., 2008; DEST, 2006; Gray, Hunter, \& Schwab, 2000; Indigenous Higher Education Advisory Council, 2008; NCVER, 2009). Recent objectives of indigenous education policy in Australia have been aimed at redressing indigenous economic and social disadvantage through increasing student retention, progression, and completion rates in both compulsory and post-compulsory education (Bradley et al., 2008).

Australia's tertiary education sector consists of the vocational education and training (VET) and the higher education (HE) sectors. Universities constitute the higher education sector. The primary focus of the HE sector is the pursuit, production, preservation, and transmission of knowledge. The main focus of the VET sector is on vocational education and training through the provision of specific and generic skills within vocationally oriented programs.

As of 2011, there were 39 universities and over 4,909 registered vocational training organisations in Australia (DEEWR, 2011b). Five universities were regarded as dual sector institutions delivering both vocational and higher education courses and programs. Of these five dual sector institutions only one, Charles Darwin University, is located in the Northern Territory. The remaining four are found in metropolitan and regional Victoria. Batchelor Institute of Indigenous Tertiary Education (BIITE), a provider of vocational and higher education programs for Indigenous people is also located in the Territory. BIITE is a residential institution for indigenous students. It draws its student population from all Australian states and territories.

In 2012, there were 1,759 vocational education providers registered in the Northern Territory (DEEWR, 2012). These providers deliver a range of programs ranging from Certificate I to Advanced Diploma level to indigenous and non-indigenous students in urban, regional and remote areas of the Territory. 
Although Batchelor Institute, Charles Darwin University, and the private providers operating in the Territory have significant indigenous student cohorts, little is known of the experiences of indigenous students in the tertiary education sector of the Northern Territory (NT).

The key research questions this project sought to address included:

- What is the retention, progression, and attrition rate among Northern Territory indigenous students in the VET sector?

- What are the pathways adopted by indigenous students in the Northern Territory in the transition from post compulsory education to work?

- What is the experience of indigenous students that transition from the VET sector to the HE sector in the Northern Territory?

The project adopted a mixed method approach to the data collection. To determine the retention, progression, and attrition rate among indigenous students in the tertiary education sector of the Northern Territory, both qualitative and quantitative data was examined. The quantitative data included CDU enrolment statistics for the period $2000-2009$ inclusive. The qualitative data was collected via interviews and focus groups conducted with indigenous students enrolled at CDU, Batchelor Institute of Indigenous Tertiary Education (BIITE) and two private VET providers. The quantitative and qualitative data also provided an insight into the pathways and experience of indigenous students as they transit from post compulsory education to work.

\section{STUDENT PROFILE AND POLICY CONTEXT}

Important recent objectives of indigenous education policy in Australia have been aimed at redressing indigenous economic and social disadvantage through increasing student retention, progression, and completion rates in both compulsory and post-compulsory education. The two sectors of the tertiary education system, Vocational Education and Training (VET) and Higher Education (HE), have usually been acknowledged as separate but crucial elements in indigenous capacity building. The vocational education sector, in particular, has had an important role in equipping indigenous people with the vocationally orientated skills required to participate in paid employment, the mainstream economy, and the labour market (Dockery \& Milson, 2007).

Despite the gains in the educational outcomes achieved by indigenous students in recent decades, only a small proportion of the total population of indigenous students access, or complete, post-compulsory education. The disparity between indigenous and non-indigenous student engagement in the HE sector is particularly significant. Demographic forces, as well as current and predicted skills shortages, are creating an opportunity and a demand for an increase in the number of indigenous students who enter the tertiary education system, return to study, and complete qualifications. As Behrendt, Larkin, Griew, and Kelly (2012, vi) acknowledged:

The transformative power of higher education underpins the prosperity of our nation and is of particular importance for Aboriginal and Torres Strait Islander communities where overcoming socio-economic disadvantage will only be achieved if members of those communities are given the capacity to assist in finding the solutions to seemingly intractable problems.

\section{Policy Context}

The Bradley Review of Australian Higher Education (Bradley et al., 2008) acknowledged the international consensus that the reach, quality, and performance of a nation's higher education system will be the key determinants of economic and social progress. An important response by the Australian Government to the 2008 Bradley review, was to set targets to increase the tertiary education participation of people from low socio-economic status and indigenous backgrounds. One potentially significant means of improving access for people from underrepresented groups in the tertiary education system is to streamline the pathways from VET to HE (Bradley et al., 2008, p. 21). 
Australia has a persistent skills shortage and, as indicated by the current enrolment trajectory, a limited capacity to meet the expected composition of the future labour market (Access Economics, 2008; Bradley et al., 2008; DEEWR, 2011a). The lack of suitably qualified and skilled people to meet medium and short term needs is, according to Bradley (2008), a threat to the well-being of the community and the country's capacity to maintain competitiveness and prosperity. As the Bradley (2008) review acknowledged to meet the forecast labour demand, Australia needs to increase the number of students who enter the tertiary education system, return to study, and complete qualifications.

There is also a growing concern that some sectors of the population are discouraged from participating in, or denied access to, the economic and social opportunities which a higher education provides (Behrendt et al., 2012; Asmar, Page, \& Radloff, 2011; Indigenous Higher Education Advisory Council, 2006, 2008). Students of low socio-economic status, indigenous students, and students from regional and remote areas are particularly at risk of being marginalised by the education system (NCVER, 2004; O'Callaghan, 2005). As the Bradley Review acknowledged:

...from 2010 the supply of people with undergraduate qualifications will not keep up with demand. To increase the numbers participating we must also look to members of groups currently under-represented within the system, that is, those disadvantaged by the circumstances of their birth: Indigenous people, people with low socio-economic status, and those from regional and remote areas. (Bradley et al., 2008, p. Xi)

Historically, indigenous people have formed one of Australia's most socially and economically disadvantaged groups (Davidson \& Jennett, 1994; Productivity Commission, 2003, 2011). The extent of indigenous disadvantage is reflected in statistics showing low levels of life expectancy, significant health problems, high unemployment, low attainment in the formal education sector, unsatisfactory housing and infrastructure, and high levels of arrest, incarceration, and deaths in custody (ABS, 2006; Attorney General's Department, 2011; Davidson \& Jennett, 1994; Productivity Commission, 2003, 2011). Indigenous people have been disadvantaged in terms of their capacity to gain access to education and by their relative inability to obtain educational qualifications (Encel, 2000; Gray, Hunter, \& Schwab, 2000). For many indigenous people living within remote regions of Australia, isolation and the inability to access mainstream service exacerbates this disadvantage (Productivity Commission, 2011).

\section{Indigenous Demographic Profile}

Aboriginal and Torres Strait Islander people represent 2.3 percent of the total Australian population (ABS, 2006, p. 12). According to the 2006 Census (ABS, 2006, p. 14), 38 percent of the indigenous population are aged under 15 years compared to 19 percent of the non-indigenous population. The median age of indigenous people is 21 years, 16 years younger than the median age for the non-indigenous population. The indigenous population is also growing at twice the annual rate projected for the rest of the population (MCEETYA, 2008, p. 4). The 2006 census (ABS, 2006, p. 13) also established that almost one third of the resident indigenous population resided in major cities (32 percent), 21 percent lived in inner regional areas, 22 percent in outer regional areas, 10 percent in remote areas, and 16 percent in very remote areas.

The indigenous proportion of the population increases with geographic remoteness. The Northern Territory for example, is one of Australia's most remote regions and indigenous people comprise approximately 32 percent of the total Territory population. According to the 2006 census (ABS, 2006, p. 14), "Of the states and territories, Northern Territory had the largest proportion [45 percent] ...of its population living in remote and very remote areas, with four-fifths [79 percent] ... of its indigenous population living in these areas." Remoteness, according to the ABS (2006) data has a significant negative impact on the attainment of educational qualifications.

The under-representation of indigenous people in the education system, particularly the Higher Education sector, has been well documented (Alford \& James, 2007; Bradley et al., 2008; DEST, 2006; Gray, Hunter, \& Schwab, 2000; Indigenous Higher Education Advisory Council, 2008; NCVER, 2009). As the Indigenous Higher Education Advisory Council has acknowledged:

The educational backgrounds of indigenous people vary by age groups and regions, but the underlying pattern of educational attainment is well below that of the non-indigenous population. The evidence of an education gap is 
apparent at multiple levels across the school years and into tertiary participation. (Indigenous Higher Education Advisory Council, 2008, p. 13)

This disparity is especially significant given the very young demographic profile of the indigenous population. As noted by the Indigenous Higher Education Advisory Council (2008, p. 14), indigenous youth represent a growing proportion of Australia's potential labour market, yet "...the picture is bleak for many indigenous students at age 15 years..." A reported 25 percent of indigenous young people cease their formal education upon leaving school (Curtis, 2008, p. 9).

The factors behind indigenous under-representation in the tertiary education sector are complex and interrelated. Whilst isolation and remoteness is a major contributing factor (Behrendt et al., 2012), high rates of poverty and its incumbent educational disadvantages; high attrition rates of indigenous students particularly in senior secondary school years; and the over-representation of indigenous students undertaking vocational rather than academic studies in Years 11 and 12 also have a significant impact on indigenous educational attainment (ABS, 2006; Indigenous Higher Education Advisory Council, 2008).

Compounding the problem is the high proportion of indigenous students undertaking vocational education studies which do not create direct pathways to higher education. The consequence is a low proportion of indigenous students who possess the prerequisites needed to enrol directly into higher education courses (Behrendt et al., 2012; Indigenous Higher Education Advisory Council, 2008).

\section{Measuring Progress}

In any discussion on student performance it is important to make the distinction between "progress" and other indicators of "performance." According to Gabb, Milne, and Cao (2006, p. 3), attrition, retention, completion, and progress, are frequently used as indicators of the quality of education. In broad terms, attrition, retention, and completion are equal to one hundred percent, whereas "progress" refers to the proportion of subjects/units passed by students. As Gabb et al. (2006, p. 3) describe, the terms, attrition, retention, completion, and progress, have a number of dimensions.

Attrition refers to the loss of students from something, retention refers to the students staying within something. Completion refers to the conclusion of something by the students and progress refers to progress of students through something. That "something" may be a unit, a module, a subject, a year of a multi-year course, a whole course or, in the case of attrition and retention, a sector within an institution, an institution, a sector of the tertiary education system, or the tertiary education system as a whole. Each is usually reported as a rate measured over a period of time, typically one year in higher education.

In the context of vocational education and training, the evaluation of "performance" utilises a range of measures such as enrolments, completion rates, pass rates, and student satisfaction measures. As Dockery and Milson (2007, p. 42) noted, one of the most widely used measure of vocational outcomes is gross employment rates - the proportion of graduates or module completers who are in employment at a given point of time after completion.

For indigenous students from the remote areas of Australia, the lack of available labour market opportunities is a significant barrier to employment (Giddy, Lopez, \& Redman, 2009; MCEETYA, 2008). Research indicates that in the more remote areas, the motivation for undertaking training does not necessarily include an expectation of employment (NCVER, 2004; O'Callaghan, 2005). A 2004 study found that in very remote regions, 27 percent of indigenous students participated in training so they could help in their community (NCVER, 2004). A similar study in 2005 found that the main reasons students undertook training was to improve knowledge (43 percent) and get a job (42 percent). Other reasons included to improve confidence, to help in the community, or to obtain skills for community/voluntary work (O'Callaghan, 2005). Although employment outcomes are greatest for course completers than for non-completers, indigenous students are less likely to persist in VET and HE courses than non-indigenous students (Curtis, 2008; DEEWR, 2008). Consequently, employment outcomes remain consistently lower for indigenous Australians' compared with other Australians (DEEWR, 2008; O'Callaghan, 2005, p. 3). 


\section{Vocational Education}

The proportional representation of indigenous students in the vocational education sector is significant and the acquisition of skills from this sector is important for indigenous people. Vocational education is also more accessible than university study in non-metropolitan areas, where over a third of high-achieving indigenous youth reside (Nguyen, 2010, p. 8). The importance of vocational education for indigenous people is reflected in the fact that almost one in four of the indigenous population aged 15-59 participated in a VET course in 2008 (DEEWR, 2008, p. 80). According to the Department of Education, Employment, and Workplace Relations (2008, p. 80), in 2008, the indigenous participation rate in vocational education was 13.4 percent and exceeded the overall national rate by more than 2 percent. In 2008, indigenous students represented 4.3 percent of all vocational education enrolments (DEEWR, 2008).

Throughout Australia there is considerable variation in the ratio of indigenous to non-indigenous participation in VET. In 2008, the ratio of indigenous to all VET students varied from a low of 1.1 percent in Victoria to a high of 45.0 percent in the Northern Territory. Indigenous participation in Western Australia, Queensland, and New South Wales was above the national average (DEEWR, 2008, p. 84). Research also indicates that indigenous enrolments in VET courses are trending upwards (DEEWR, 2008; Nguyen, 2010). Nationally, there was a 27 percent growth in the number of indigenous VET students between 2001 and 2008 (DEEWR, 2008, p. 84). Since 2001 there been significant increase in indigenous enrolments in the areas of commencing apprentices and apprentices-in-training. From 2001 to 2008 the total number of indigenous apprentices-in-training increased by 95 percent (DEEWR, 2008, p. 80).

Historically, the VET programs that have a significant indigenous enrolment include mixed-field programs which provide interpersonal and job search skills (ABS, 2002, p. 111; NCVER, 2010, p. 11). Indigenous students are also concentrated in management and commerce, engineering and related technologies, and society and culture programs. Indigenous VET students are more likely than non-indigenous students to undertake courses in the areas of health, education, agriculture, environmental and related studies, and creative arts (DEEWR, 2008, p. 87; NCVER, 2010, p. 11).

The demographic profile of indigenous vocationalleducation students is however, significantly different to that of non-indigenous students. According to DEEWR (2008, p. 80), indigenous students tend to be younger than non-indigenous students; they are much more likely to be living in remote locations; they have much lower levels of schooling upon commencement of vocational education, and because of the low levels of educational attainment, concentrate on Certificate I and II Australian Qualification Framework courses. In 2008, 41.9 percent of indigenous VET students were enrolled in Certificate I and II courses, compared to 23.5 percent of non-indigenous students. Approximately 30.5 percent of indigenous students were enrolled in Certificate III, Certificate IV, and Diploma courses, compared to 51.3 percent of non-indigenous students (DEEWR, 2008, p. 208).

Nationally, there are more indigenous males enrolled in VET than females. In 2008, indigenous males constituted 53.5 percent of the indigenous VET enrolments and females 46.5 percent (DEEWR, 2008, p. 79). The indigenous gender balance is broadly consistent with the VET enrolments for all students. In 2010, 52.4 percent of all VET enrolments were male and 47.6 were female (NCVER, 2010, p. 9).

For the majority of indigenous students, their vocational education experience has been positive (DEEWR, 2008; O'Callaghan, 2005). In 2008, a reported 91 percent of indigenous vocational education graduates indicated they had "...achieved their main reason for study" (DEEWR, 2008, p. 80). However, despite the increase in enrolments and the apparent importance and attractiveness of vocational education the retention and completion and re-enrolment rates of indigenous students are consistently below that of their non-indigenous counterparts (DEEWR, 2008, p. 92). As O'Callaghan (2005, p. 5) noted, the issue is not one of participation in VET but of retention, completion and (re-) enrolment in higher level, industry-relevant courses most likely to lead to employment and economic outcomes. Standard labour market indicators, such as employment status and earnings are, according to Dockery and Milson (2007, p. 33), “....accepted... [and]...appropriate outcome measures for indigenous people who participate in mainstream programs." 


\section{The Pathways from Education to Work}

The pathways from post-compulsory schooling to work are varied. For many students the traditional school to work transition involves either vocational education and training or higher education. However, since the 1980's collaboration between the between the HE and the VET sectors has been growing and, in recent years, the inter-sectorial movement of students between Vocational Education and Higher Education has increased (Harris, Raine, \& Sumner, 2005; Moodie, 2010). As Harris et al. (2005, p. 10) noted, student 'traffic' between VET and other sectors has grown "... with students from VET going on to university as well as being admitted to university on the basis of their VET studies." For many students the transition from VET to HE has become a viable and attractive means of obtaining additional qualifications and skills. As Harris et al. argued:

In a society committed to lifelong learning, and with an economy requiring a knowledgeable, skilled, flexible, and adaptable labour force, it is essential that there are clear and easy pathways between the Vocational Education and Training (VET) and Higher Education sectors. Such inter-sectoral movement is important for reasons of equity and efficiency. (Harris, Raine, \& Sumner, 2005, p. 6)

The connection between VET and HE has been identified as an important element to achieving national attainment and participation goals and is driving an evolution of dual sector universities (Bradley et al., 2008; University of Ballarat \& Swinburne University of Technology, 2010).

Due to low year 12 completion rates, the potential pool of indigenous students with the appropriate qualifications to enter higher education through the mainstream pathway is relatively small (Indigenous Higher Education Advisory Council, 2008, p. 15; MCEETYA, 2008, p. 12). Consequently, the pathway from VET to HE has the capacity to increase indigenous engagement with the tertiary education sector, particularly higher education. However, a review of the literature has revealed that there is limited research on indigenous students who transition from VET to HE. Therefore, little is known of the experiences of indigenous students who follow this pathway.

One study that investigated a cohort of transitioning indigenous students was conducted at the University of South Australia in 1997 (Ramsey et al., 1997). The study found that of the 223 commencing indigenous students, eight had gained admission on the basis of prior vocational study. The majority of the students received no credit transfer and were reported to have the lowest "success" rate of all student cohorts. Given the lack of additional research, and the fact that this study is over 12 years old, there is a clear need for research on the VET to HE pathways undertaken by indigenous students.

It should be noted that the tertiary education pathways that indigenous students take is often different from the norm. Whilst it is acknowledged that alternative entry and pathways are critical elements for assisting indigenous access to higher education, a significant number of indigenous students are precluded from gaining higher education admission via articulation, due to the level of their vocational qualification (DEEWR, 2008; Department of Education Science Training, 2006). Most commencing higher education indigenous students enter university via an alternative route. According to DEST (2006, p. 93) in 2004, 32 percent of higher education commencing indigenous students had no formal qualifications and 66 percent gained admission via special entry arrangements.

\section{Indigenous Participation in Higher Education}

It is widely acknowledged that indigenous students are significantly under-represented in the Australian Higher Education System (DEEWR, 2008; Indigenous Higher Education Advisory Council, 2006, 2008; O'Callaghan, 2005). It is also acknowledged that $\mathrm{HE}$ indigenous students have high attrition rates, low retention, and completion rates and high failure rate (DEEWR, 2008; Indigenous Higher Education Advisory Council, 2008). The attrition rate of indigenous students is particularly significant. Up to 35 percent of indigenous students do not progress beyond their first year of HE study (Indigenous Higher Education Advisory Council, 2006).

Whilst statistics indicate that the number of indigenous HE commencing student's is increasing, participation in HE is approximately less than half the rate, if parity with non-indigenous people existed (DEEWR, 
2008; Indigenous Higher Education Advisory Council, 2008). In 2008, indigenous people comprised only 1.29 percent of the commencing domestic HE student population and there are, according to DEEWR (2008, p. 116), “... indications of a long term widening of the gap between indigenous and non-indigenous participation."

Historically, a high proportion of HE indigenous students enrol in Humanities courses (ABS, 2002, p. 113). In 2008, approximately one third of all HE indigenous enrolments were in courses broadly defined as "Society and Culture" (DEEWR, 2008, p. 117; Indigenous Higher Education Advisory Council, 2008, p. 11). In 2008, health, education, and society and culture courses accounted for approximately 70 percent all HE indigenous enrolments. In recent year's management and commerce courses have also begun to attract more indigenous students. However, the most significant increase in enrolment has been in health related programs (DEEWR, 2008, p. 117). This may be a reflection of the growing importance indigenous people place on of health issues.

Nationally, more indigenous women enrol in HE courses than indigenous men. In 2008, 67.1 percent of commencing HE Indigenous enrolments were female and 32.9 percent were male (DEEWR, 2008, p. 223). This is broadly consistent with the gender balance for all commencing HE students. However, between the period 2001 and 2008 , indigenous female enrolments have been trending upwards and have increased by 10.1 percent. For the same period, indigenous male enrolments decreased by 5.2 percent (DEEWR, 2008, p. 223).

The gap between indigenous and non-indigenous HE participation is most significant in the area of postgraduate study. As the Indigenous Higher Education Advisory Council (2008, p. 4) acknowledged, “...the disparity in enrolment, participation, and especially completion rates of indigenous post-graduate students is dramatic." In 2006, indigenous students constituted only 0.3 percent of Doctorate and 0.6 percent of Masters by Research completions. To achieve parity of participation, the number of indigenous doctoral students needs to more than triple and completions need to increase by more than 600 percent (Indigenous Higher Education Advisory Council, 2008, p. 4).

According to DEEWR (2008, p. 130), there is a continuing demand for indigenous HE graduates. However, employment outcomes for indigenous graduates have, for the past six years reminded consistently lower than that of their non-indigenous counterparts. In addition, the average starting salary for indigenous graduates is also significantly less. According to DEEWR (2008, p. 130), in 2008, the average indigenous graduate commencement salary was $\$ 4,000$ less than that of a non-indigenous graduate.

\section{METHODOLOGY}

Consistent with contemporary social and educational research, this project employed a mixed method approach to the research (Creswell \& Tashakkori, 2008; Greene, 2008). Broadly speaking, a mixed analysis involves using quantitative and quantitative data analysis techniques within the same study. It is a synthesis that contains idea from qualitative and quantitative research and involves mixing or combining quantitative and qualitative research techniques, methods, approaches, concepts, or language into a single study (Onwuegbuzie \& Combs, 2011). According to Salehi and Golafshani:

Quantitative method includes numerical values and measurement which helps researchers to describe and determine some patterns, such as human's social patterns, using deductive logic. Qualitative method deals with interpretation and exploration which guide researchers to understand and explain events and occurrences, such as human phenomenon from the social patterns. (2010, p. 187)

\section{Advantages of Mixed Methods}

Although mixed methods research is not a new research paradigm it has, according to Onwuegbuzie, Turner, and Johnson (2007), arisen because of an inherent "tension" between quantitative research and qualitative research methods. Qualitative research, alone, has received criticism in the past with issues based on questions of clarity, methodological transgressions, and insufficient justification for the mixing of methodological approaches (Goulding, 1999). However, neither a qualitative nor a quantitative methodological approach has universal applicability (Patton, 1980). Thus, combining both methodologies and interpreting both primary and secondary data 
together, is expected to be more fruitful. Mixed methods recognise the importance of traditional quantitative and qualitative research but also offer a third paradigm choice that often results in more informative, complete, balanced, and useful research results (Onwuegbuzie, Turner, \& Johnson, 2007, p. 129).

The advantages of employing mixed research methodology have been well documented (Pole, 2007; Rossman \& Wilson, 1985; Sieber, 1973). A widely recognised advantage of incorporating both quantitative and qualitative data analysis in a single study is that it can provide for stronger inferences because the data are examined from multiple perspectives (Onwuegbuzie \& Combs, 2011; Pole, 2007). Mixed methods also enable the researcher to simultaneously answer confirmatory and exploratory questions (Pole, 2007); triangulate the research data (Onwuegbuzie \& Combs, 2011); and examine processes and experiences along with outcomes (Klassen et al., 2012). According to Stringfield et al. (2012), the flexibility of mixed methods research strategies also makes such approaches especially suitable for multi-site case studies. As this research project involved obtaining data from multiple sites, the combination of quantitative and qualitative data provided a depth and a perspective to the research problem that would not have been possible with a single data source. The inductive nature of this research also necessitated a coupling of qualitative and quantitative approaches.

\section{Triangulation}

In the context of this research, methodological triangulation was achieved by combining input from qualitative data obtained from focus groups and interviews, with the quantitative data from Charles Darwin University vocational and higher educational enrolment statistics. The quantitative data was obtained from enrolment information for the period 2000-2009 inclusive. Excel was used to analyse the qualitative data. To preserve confidentiality all students were de-identified in the statistical data and only aggregates results were utilised in the data analysis.

The qualitative data was obtained through interviews and focus groups with past and present Northern Territory Indigenous vocational and higher education students. The interview schedule was pre-tested prior to conducting the interviews. Based on the feedback received during the interview pre-test, minor changes were made to the schedule before the interviews commenced. Twenty nine interviews and two focus groups were conducted (see supporting documentation for interview and focus group questions). The interviewees and focus group participants had completed a minimum of one VET competency at either Charles Darwin University; Batchelor Institute; the Council for Aboriginal Alcohol Program Services (CAAPS); or with the private training provider, Alana Kaye Training. The participants were chosen at random from enrolment data supplied by the respective institutions. Ten interviewees were students at CDU, nine were students at BIITE and ten interviewees were sourced from private VET providers. The interview contained a mixture of closed an open-end ended questions. Excel was used to analyse the interview data.

\section{QUANTITATIVE DATA ANALYSIS}

The following data analysis of indigenous student engagement with the VET and HE sectors of Charles Darwin University is based on enrolment date for the period 2000-2009 inclusive. The focus of this analysis was primarily on the VET sector. However, indigenous progression from VET to HE is also examined. The years 20052009 represented a period of high indigenous enrolment in the VET and HE sectors of CDU. Consequently, this period was examined in detail with regard to preferred course enrolment, retention, and completion rates. A detailed quantitative analysis is contained in the supporting documentation that accompanies this report.

\section{Indigenous Participation in Vocational Education and Training}

As indicated in Figure 1, in the period 2000 to 2009 the indigenous and non-indigenous VET enrolment cohorts followed a similar trajectory. Whilst there has been growth in both enrolments cohorts over time, this growth has not been consistent. Peak enrolment activity for both cohorts occurred in 2006-2007. This peak was followed by a significant decline in enrolment in 2008. The years 2005-2009 represented a period of relatively high indigenous engagement in the VET sector of CDU. 


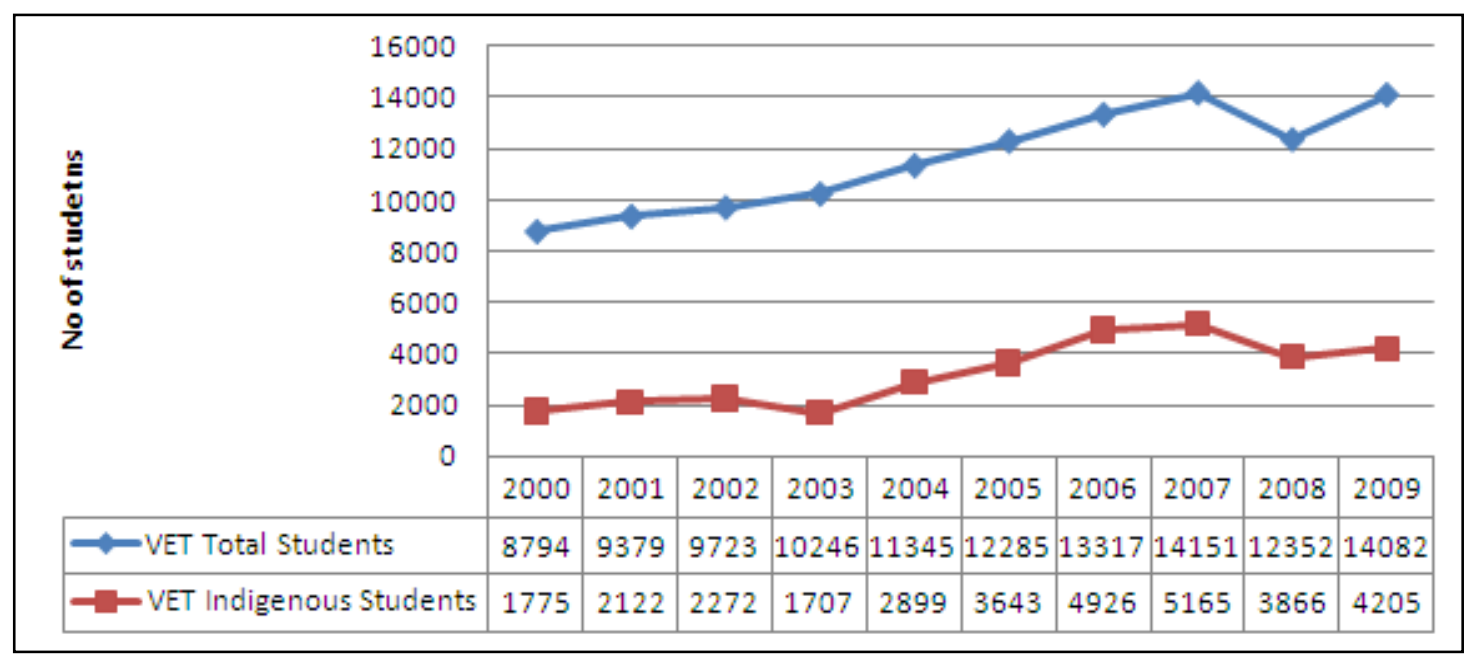

Figure 1: 2000-2009 Indigenous and Non Indigenous VET Student Enrolments (Actual Student Numbers)

In the decade commencing in the year 2000, indigenous students represented an average of 27.3 percent of the total VET enrolments. Indigenous enrolment ratio ranged from a low 17.7 percent in 2003 to a high 37 percent in 2006. The percentage increase in indigenous student enrolments from 2000-2009 was approximately 176 percent.

\section{Enrolment by Age}

An analysis of the CDU enrolment data indicates that there has been an increase in indigenous student enrolments in all age categories since 2000. Whilst students under the age of 29 dominated in terms of actual student numbers, the cohort with highest number of enrolments was under 20 years of age.

As indicated in Table 1, indigenous VET enrolments in the under 20 age group have, with the exception of 2007, been consistently higher than any other age cohort. Across the decade this cohort constituted approximately 41 percent of all indigenous VET enrolments. This was followed by 28.2 percent in the 20-29 year age group, 25.6 percent in the 30-39 years age cohort and 20.9 percent in the cohort aged 40-49. The cohort with the least number of indigenous enrolments was the 50 plus age group with only 14 percent of enrolments. Indigenous students in all age groups constituted less than 50 percent of the total VET enrolments.

Table 1: 2000-2009 Indigenous VET Enrolments as a Percentage of Total VET Enrolments

\begin{tabular}{lccccccccccc}
\hline & $\mathbf{2 0 0 0}$ & $\mathbf{2 0 0 1}$ & $\mathbf{2 0 0 2}$ & $\mathbf{2 0 0 3}$ & $\mathbf{2 0 0 4}$ & $\mathbf{2 0 0 5}$ & $\mathbf{2 0 0 6}$ & $\mathbf{2 0 0 7}$ & $\mathbf{2 0 0 8}$ & $\mathbf{2 0 0 9}$ & Average \\
\hline$<\mathbf{2 0}$ yrs & $39 \%$ & $43 \%$ & $45 \%$ & $35 \%$ & $40 \%$ & $44 \%$ & $47 \%$ & $41 \%$ & $38 \%$ & $39 \%$ & $41.1 \%$ \\
$\mathbf{2 0}-\mathbf{2 9}$ yrs & $21 \%$ & $23 \%$ & $23 \%$ & $21 \%$ & $29 \%$ & $30 \%$ & $36 \%$ & $38 \%$ & $32 \%$ & $29 \%$ & $28.2 \%$ \\
$\mathbf{3 0}-\mathbf{3 9}$ yrs & $15 \%$ & $18 \%$ & $19 \%$ & $18 \%$ & $21 \%$ & $27 \%$ & $38 \%$ & $38 \%$ & $31 \%$ & $30 \%$ & $25.5 \%$ \\
$\mathbf{4 0}-\mathbf{4 9}$ yrs & $13 \%$ & $13 \%$ & $15 \%$ & $14 \%$ & $15 \%$ & $20 \%$ & $31 \%$ & $32 \%$ & $29 \%$ & $27 \%$ & $20.9 \%$ \\
$>\mathbf{4 9}$ yrs & $9 \%$ & $8 \%$ & $9 \%$ & $10 \%$ & $11 \%$ & $13 \%$ & $22 \%$ & $22 \%$ & $18 \%$ & $18 \%$ & $14 \%$ \\
\hline
\end{tabular}

\section{Indigenous Enrolment by Gender}

Enrolment data indicates that significantly more indigenous male students enrolled in VET programs at CDU than indigenous female students. Indigenous male enrolments constituted approximately 59.4 percent of all indigenous enrolments and female enrolments were in the vicinity of 40.6 percent.

According to Larkin (2011, p. 6), VET indigenous gender enrolment patterns at CDU are significantly different to that of their non-indigenous counterparts. In the period 2000-2009 non-indigenous male and female enrolments were near parity. Non-indigenous males constituted approximately 52 percent of all non-indigenous student enrolment and non-indigenous females represented 48 percent. In the same period indigenous female students represented 24.4 percent of the total female VET enrolments and indigenous males constituted 27.6 percent of all male VET enrolments. 


\section{Multiple Course Enrolments}

Between 2000 and 2009, there was a disparity between the number of actual indigenous students engaged in VET at CDU and the number of indigenous students enrolled by course. Indigenous course enrolments exceed the actual student numbers in 2001 and in subsequent years. This disparity indicates that a proportion of indigenous VET students enrolled in more than one VET course in a given year.

With the exception of 2000, multiple course enrolments have been a consistent feature of indigenous VET engagement at CDU. Between 2005 and 2009 the average number of indigenous students involved in multiple course enrolments was 1100, or 25.5 percent of the total indigenous student body. According to Larkin (2011, p. 8), for the same period, 18.6 percent of non-indigenous students were enrolled in multiple VET courses.

\section{Course Enrolment Numbers}

Between 2000 and 2009, indigenous students were enrolled predominantly in Certificate I and Certificate II courses. Certificate I course enrolments have, over time, undergone periods of considerable growth and decline. Indigenous enrolments in Certificate I peaked in 2006 with 3357 enrolments and then experienced a decline in 2007 and 2008.

In 2008 and 2009, Certificate II enrolments exceed Certificate I enrolments. This however, may be a result of students progressing on to Certificate II after completion of a lower level course. Diploma enrolments were consistently very low and advanced diploma enrolments were virtually non-existent for indigenous students across the decade.

The pattern of indigenous enrolment in Certificate level courses was in marked contrast to that of nonindigenous enrolments. As demonstrated in Table 2, indigenous course enrolments were skewed towards Certificate I level courses whilst non-indigenous course enrolments were more significant at the Certificate III, IV, Diploma, and Advanced diploma course levels. Between 2000-2009, indigenous enrolment constituted on average, less than one percent of total enrolments at the Advanced Diploma level, seven percent of enrolment in Diploma courses, 9.5 percent of enrolments in Certificate IV courses, 14.7 percent of enrolment in Certificate III, and 30.9 percent and 61.5 percent of enrolments in Certificate II and Certificate I courses respectively.

Indigenous enrolment in Certificate I courses have consistently been high and have ranged from 54 percent to 68 percent of the total enrolment. In comparison, non-indigenous enrolment at the advanced diploma level has constituted, on average, more than 99.4 percent of the total enrolment.

Table 2: 2000-2009 Indigenous VET Course Enrolment as a Percentage of Total Course Enrolment

\begin{tabular}{lccccccccccc}
\hline & $\mathbf{2 0 0 0}$ & $\mathbf{2 0 0 1}$ & $\mathbf{2 0 0 2}$ & $\mathbf{2 0 0 3}$ & $\mathbf{2 0 0 4}$ & $\mathbf{2 0 0 5}$ & $\mathbf{2 0 0 6}$ & $\mathbf{2 0 0 7}$ & $\mathbf{2 0 0 8}$ & $\mathbf{2 0 0 9}$ & Average \\
\hline Certificate I & $61 \%$ & $63 \%$ & $64 \%$ & $54 \%$ & $58 \%$ & $61 \%$ & $68 \%$ & $63 \%$ & $60 \%$ & $63 \%$ & $61.5 \%$ \\
Certificate II & $19 \%$ & $21 \%$ & $25 \%$ & $23 \%$ & $32 \%$ & $32 \%$ & $33 \%$ & $42 \%$ & $43 \%$ & $39 \%$ & $30.9 \%$ \\
Certificate III & $13 \%$ & $10 \%$ & $10 \%$ & $11 \%$ & $13 \%$ & $16 \%$ & $20 \%$ & $20 \%$ & $17 \%$ & $17 \%$ & $14.7 \%$ \\
Certificate IV & $8 \%$ & $10 \%$ & $8 \%$ & $9 \%$ & $8 \%$ & $10 \%$ & $12 \%$ & $8 \%$ & $11 \%$ & $11 \%$ & $9.5 \%$ \\
Diploma & $2 \%$ & $4 \%$ & $6 \%$ & $9 \%$ & $6 \%$ & $13 \%$ & $7 \%$ & $9 \%$ & $7 \%$ & $8 \%$ & $7.1 \%$ \\
Advanced Diploma & $1 \%$ & $1 \%$ & $0 \%$ & $2 \%$ & $2 \%$ & $0 \%$ & $0 \%$ & $0 \%$ & $0 \%$ & $0 \%$ & $0.6 \%$ \\
\hline
\end{tabular}

\section{Course Completion Rates}

This report acknowledges that there are a number of statistical issues to be taken into account in respect to an analysis of indigenous and non-indigenous course completion rates. These issues include:

- $\quad$ Students may not complete their course in one year.

- Courses at different levels take varying lengths of time to complete - some courses may be of more than one year duration.

- $\quad$ Students studying part time will take longer to complete a course. 
In comparing indigenous and non-indigenous course completion rates, the issues are similar for both student cohorts and are somewhat negated.

Low course completion rates and a high attrition rate were the hallmark of indigenous engagement in the VET sector in the period 2000-2009. The highest percentage of course completions occurred at the Certificate I and II levels. In the period 2000-2009, Certificate I had a 52 percent course completion rate and Certificate II a 25 percent completion rate. The completion rates in both Certificate I and II fluctuated considerably and ranged from a high 74 percent to a low, 12 percent.

Across the decade Certificate III, IV, and Diploma students had very low completion rates. No indigenous students completed an advanced diploma. Over the decade the total indigenous course completion averaged 16.8 percent.

According to research conducted at CDU, non-indigenous students experience just over twice the success rate of indigenous students as measured by course completions (Larkin, 2011, p. 20).

\section{5 - 2009 Field of Study Enrolment, Completion, and Success Rates}

Between 2005 and 2009, indigenous students constituted approximately 34 percent of all course enrolments in the VET sector of CDU. The total enrolment over this period was 5892 students. Of these students approximately 10 percent, or 576 students, were recorded as having completed their course. For the same period indigenous students accounted for 42 percent of all Certificate I course completions, 22 percent of Certificate II completions, and 25 percent of Certificate III, IV, Diploma, and Advanced Diploma completions.

The fields of study with the highest number of enrolments were - by order of magnitude: agricultural environmental and related studies; mixed field programmes; management and commerce; engineering and related technologies; and education. Approximately 70 percent of all indigenous enrolments were in these fields of study.

The fields of study with the highest number of course completions included: agricultural environmental and related studies; food hospitality and personal services; management and commerce; and engineering and related technologies. These fields of study accounted for approximately 78 percent of all indigenous course completions. The courses with the greatest success rates were in the areas of natural and physical sciences; ${ }^{1}$ food hospitality and personal services; management and commerce; and information technology.

Courses in the areas of agricultural environmental and related studies, had the highest number of course enrolments and the highest number of course completions but overall, a relatively low indicative success rate of 12 percent.

The fields of study with a high attrition rate include mixed field programmes; health; architecture and building; and education. The mixed field programs, whilst being the second most popular field of study in terms of indigenous student enrolment, had an indicative success rate of just 1 percent.

\section{Indigenous Participation in Higher Education}

Table 3 below, indicates the proportion of indigenous students enrolled in HE courses at CDU for the period 2000-2009 inclusive. The data includes indigenous student enrolments across all under-graduate and postgraduate courses, enabling courses, non-award courses, HE diplomas, Advanced Diplomas, and Associate Degrees. Indigenous enrolments represented an average of 4.8 percent of the total HE population at CDU during this period.

${ }^{1}$ Note- only one Indigenous student was enrolled in this course. 
Table 3: 2000-2009 Indigenous and Non Indigenous HE Enrolment (Actual Student Numbers)

\begin{tabular}{lccccccccccc}
\multicolumn{10}{c}{ and as a Percentage of Total Enrolment } \\
\hline & $\mathbf{2 0 0 0}$ & $\mathbf{2 0 0 1}$ & $\mathbf{2 0 0 2}$ & $\mathbf{2 0 0 3}$ & $\mathbf{2 0 0 4}$ & $\mathbf{2 0 0 5}$ & $\mathbf{2 0 0 6}$ & $\mathbf{2 0 0 7}$ & $\mathbf{2 0 0 8}$ & $\mathbf{2 0 0 9}$ & Average \\
\hline $\begin{array}{l}\text { Indigenous } \\
\text { enrolments }\end{array}$ & 255 & 258 & 265 & 267 & 274 & 294 & 269 & 300 & 287 & 331 & 280 \\
\hline $\begin{array}{l}\text { Non- } \\
\text { Indigenous } \\
\text { enrolments }\end{array}$ & 5268 & 5577 & 5789 & 5757 & 5447 & 5363 & 5468 & 6074 & 6499 & 7011 & 5825.3 \\
\hline $\begin{array}{l}\text { Indigenous } \\
\text { enrolment as } \\
\text { a \% of total } \\
\text { enrolment }\end{array}$ & $4.84 \%$ & $4.63 \%$ & $4.58 \%$ & $4.64 \%$ & $5.03 \%$ & $5.48 \%$ & $4.92 \%$ & $4.94 \%$ & $4.42 \%$ & $4.47 \%$ & $4.82 \%$ \\
\hline
\end{tabular}

According to CDU enrolment data, approximately 86.6 percent of $\mathrm{HE}$ indigenous students enrolled in an Under-Graduate program and 13.4 percent enrolled in post-graduate programs. Enrolments numbers in both the under-graduate and post-graduate programs were relatively stable over time.

\section{Basis of Admission}

There are six 'Bases of Admission' (BOA) categories for entry into HE at CDU. The categories include: Tertiary Enabling Programs and Indigenous pre-admission program, VET study, mature age entry, secondary education, previous HE study, and other entry - which includes employment experience, institutional assessment, special entry, and open learning courses.

The Higher Education BOA data in respect to indigenous students was only available for the years 20052009. The available data is summarised in Table 4. According to CDU enrolment data, indigenous students utilised a variety of pathways to obtain admission into under graduate and post graduate courses. On average, approximately 21.6 percent of students gained admission each year on the basis of their secondary education results, 15 percent gained admission on the basis of their VET studies, and 30.6 percent $\mathrm{s}$ on the basis of their previous HE studies. Alternative entry pathways accounted for approximately 33.2 percent $\mathrm{HE}$ admissions each year.

Table 4: 2005-2009 Indigenous Higher Education BOA (Percentage)

\begin{tabular}{|c|c|c|c|c|c|c|}
\hline BOA & 2005 & 2006 & 2007 & 2008 & 2009 & Average \\
\hline TEP & 3.3 & 1 & 1 & 2.4 & 4.2 & 2.3 \\
\hline VET & 25.2 & 8.5 & 16.1 & 7.2 & 17.7 & 15 \\
\hline Mature age & 15.1 & 12.7 & 6.4 & 15.6 & 11 & 12.1 \\
\hline Secondary Education & 24.3 & 24.4 & 22.5 & 21.6 & 15.2 & 21.6 \\
\hline Previous HE course & 17.6 & 28.7 & 34.4 & 45.7 & 25.4 & 30.6 \\
\hline Other & 14.2 & 24.4 & 19.3 & 10.8 & 25.4 & 18.82 \\
\hline
\end{tabular}

\section{Indigenous Participation and Outcomes in Under Graduate Programs}

In the period 2005-2009, there were a total of 471 indigenous under-graduate student enrolments. The enrolments were spread across 73 courses. The most popular courses for indigenous students were in the areas of nursing and education, followed by law, business, and behavioural science.

The pattern of outcomes for indigenous students enrolled in HE under-graduate programs between 20002009 is demonstrated in Figure 2. It must be noted when interpreting this data that students enrol at different times during the academic year and are represented in each year's data category without differentiation. Consequently, the data contained in Figure 2 represents both past and continuing students. 


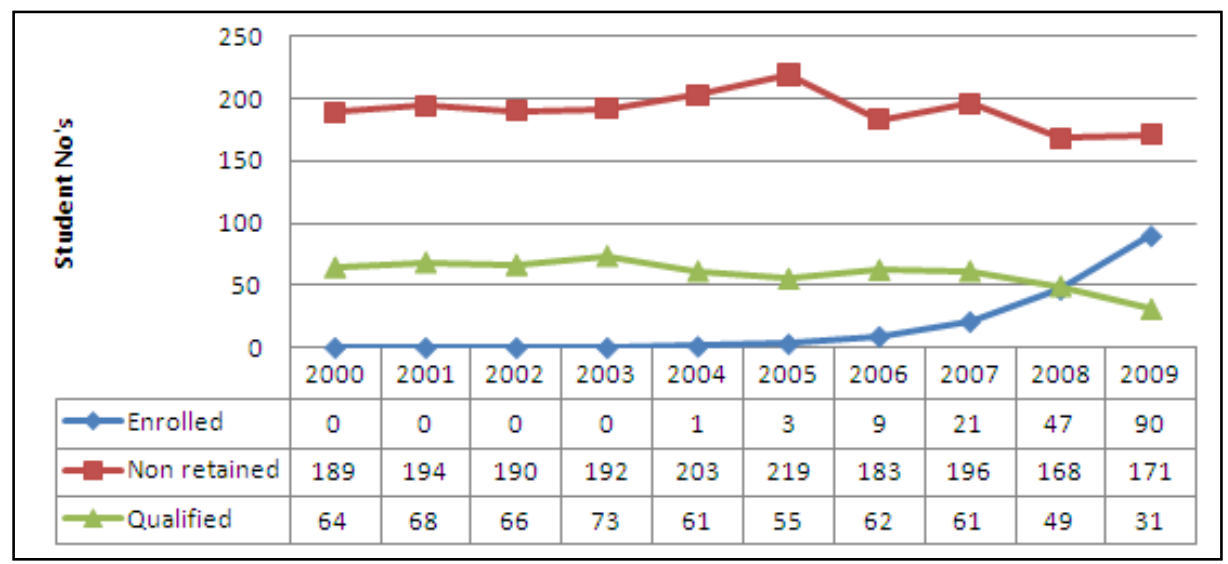

Figure 2: 2000-2009: Indigenous Undergraduate Outcomes and Participation (Actual student Numbers)

The "Enrolled" category represents retained enrolments. The "Non-retained" category includes students who have dropped out of the course, were classified as "Intermit" students, or were regarded as "Inactive" students. According to Larkin $(2011$, p. 44) the descriptor "Inactive" is a strong indicator of withdrawal from studies. The "Qualified" category also includes students who chose an alternative exit point in their course.

As indicated in Figure 2, indigenous engagement in HE under-graduate programs is characterised by a low graduation rate and a high rate of non-completions. Approximately 25 percent of under-graduate enrolments in the period 2000-2009 completed their course (Larkin, 2011, p. 42). The remaining 75 percent either dropped out or were "Inactive." Research also indicated that the majority of under graduate course withdrawals occurred during the first year of study (Larkin, 2011, p. 67).

\section{Indigenous Participation and Outcomes in Post Graduate Programs}

The CDU post-graduate courses with an indigenous intake include Graduate Certificate, Graduate Diploma, Masters, and Doctoral programs. CDU enrolment data indicates very modest numbers of indigenous students undertake post-graduate studies. In the period 2005-2009 an annual average of 37 indigenous students were enrolled in post-graduate studies. Of these 37 students, on average 46.4 percent graduated, 44.6 percent dropped out, and 6.7 percent were still enrolled. The drop-out pattern, accepting the relatively small numbers analysed, indicates a trend for indigenous students withdrawing from their courses in their second year of study.

\section{QUALITATIVE DATA ANALYSIS}

The qualitative data was collected from 29 interviews and two focus groups. Ten of the interviewees were students at Charles Darwin University, nine were students at Batchelor, and the remaining ten were undertaking study with a private provider. The interviews and focus groups occurred, where possible on-site, at the respective institutions. Three interviews were conducted over the phone.

The 10 participants in the focus group conducted at Batchelor had relocated to undertake their studies. They were studying Certificate I, II, and III in foundation English and, for the majority of the students, English was not the main language spoken at home. These students were all studying part-time.

The employment status of the interviewees varied. Approximately 59 percent were engaged in full-time employment; 10 percent were employed part-time, and 31 percent were either looking for work or undertaking volunteer activities.

The six students who participated in the focus group at CDU were studying courses that ranged from Certificate II in VET to under-graduate HE degree programs. All HE students had progressed through VET pathway and had previously undertaken a number of VET courses at Certificate I, II, III, and IV level. The CDU cohort was fluent in English. The majority of these students were studying full-time. 


\section{Motivation, Quality of the Course, and Support Received}

The following section examines the interviewee's motivation to study, the financial support, as well as any additional assistance they received. The student's perceived satisfaction and dissatisfaction with their educational experience is also discussed in this section.

\section{Motivation to Study}

Although the status of the interviewees varied, work related requirements were the most commonly cited reason for undertaking VET study. In order of frequency of response and relative importance, the main motivation to study included:

1 I wanted extra skills for my job/to help me in my job.

2 It was a requirement of my job.

3 To get a job.

$4 \quad$ Knowledge acquisition, self-esteem, self-confidence, and self-efficacy.

Study Assistance

All interviewees had received some form of financial assistance whilst studying. Some students received financial assistance from more than one source. Approximately 41 percent received financial assistance from their employer, 38 percent received Abstudy, 21 percent received financial support from their family, 17 percent received government support, ${ }^{2} 10$ percent were in receipt of Austudy/Youth allowance;, and 7 percent had financial support from their community. Only the students studying at BIITE received financial assistance from their community. BIITE students also received more financial support from their families than the other three cohorts. Eighty percent of the students undertaking study with a private provider received financial assistance from their employer.

A range of additional assistance was provided to the students. The additional support included tutorial assistance, transport, accommodation, books, computer assistance, help from indigenous support workers, time off work, cultural leave, additional time to complete the course, assistance from family and community, and assistance with child/family care. However, the type of assistance varied between institutions and individuals.

Students studying at CDU mainly received tutorial support, time off work, and help with child/family care. Students studying with CAAPS mainly received support in terms of time off work, additional time to complete the course, and cultural leave. Alana Kaye students received time off work, help with transport, and additional time to complete the course.

The students studying at BIITE received the most additional support. As these students had to relocate to undertake their studies they received assistance in the form of transport, food, and accommodation. They also received tutorial assistance on-site at Batchelor as well as assistance with books and computers, help from indigenous support workers, cultural leave, additional time to complete the course, assistance from family and community, and assistance with child/family care. Anecdotal interview comments indicated that students would have liked to receive more financial assistance, assistance with English, more computer training, and tutorial support in their community.

\section{Quality of the Course}

Overwhelmingly the students were satisfied with the quality of their course. The area where all students expressed the most satisfaction was in the quality of the teachers and tutors. The other areas of satisfaction included the cultural appropriateness of the course and the opportunity to interact with other indigenous students. The flexibility of the course, teachers or institute, and allowing time off for family/community business was also highly regarded by the interviewees.

\footnotetext{
${ }^{2}$ Some students chose to receive a "pension" rather than Abstudy as they would have forfeited other benefits and entitlements if on Abstudy. However, these students, once they were in receipt of a "pension" were subject to Income Management as applied under the Federal Governments Intervention Program.
} 
The areas that some students expressed dissatisfaction with included the lack of indigenous teachers, the level of financial support received, the lack of childcare facilities, the length of the course, and the distance travelled to undertake the course. The students from the remote areas also expressed an anxiety about having to move away from their community and family to study and the lack of tutors in remote areas, "We [would] like tutor support at Groot Eylandt ... We['d] like support in Elcho Island ... We would like tutorial assistance back home."

\section{Outcomes of Participating in VET}

For the majority of students their participation in VET was a positive experience. The outcomes varied between students, but included increased employment and career prospects, increased self-confidence and selfesteem, and opportunities to contribute to their family and community.

As indicated previously, 69 percent of the interviewees were in some form of paid employment. A further 14 percent were actively seeking work. The following anecdotal comments indicate that participating in VET had improved some student's career prospects and employment aspirations:

Employer impressed by the study done. Given more opportunity to attack a variety of job options ... Gained an increase in wage by having a certificate ... Has helped with work because of increased confidence ... Given [me] lots of skills and job tasks such as time management and dealing with people ... The study was helpful in getting me looking for a job ... [I] was able to fill in log-books, accident reports etc. [obtained] computer skills ... Good for CV. Has helped to improve [my] CV and job applications. Good to have a qualification.

Many students also indicated that participation in VET had enabled them to assist their family and community. As the following anecdotal comments indicate the skills, knowledge, and confidence acquired in their study had enabled some students to communicate with others more effectively and to contribute to their family and community:

Now closer to my teenage son [I] can help with homework... [I have] gained respect of wife, family and community ... [Assisted with] with filling out forms, speaking to get things done like family matters ... Helped me with community meetings [as an interpreter] when Power and Water come ... Feel confident to help people in my community [I] can be the educated voice to speak to others and help by being a representative.

For many students the positive outcomes were more personal. As the students anecdotal comments indicate, improved self-confidence and self-esteem, improved English competence, and self-satisfaction were among the personal benefits student achieve through participating in VET:

[increased] self-discipline and knowledge of the areas of study and life in general ... Expanded vocabulary ... More confident ... Feeling more knowledgeable and satisfied with opportunities ... Inspiring me to study more and look at the bigger picture ... It has given me the drive to keep going both personally and professionally ... Better now at reading and writing. Having the certificate I have achieved something - personal satisfaction. [Study] gave selfconfidence and self-esteem ... Make me more confident-easier to read newspapers and books.

\section{VET to HE Pathway}

A small percentage of the interviewees (approximately 17 percent) had unitised their VET studies to gain entry into HE. Approximately 80 percent of these students indicated that they had received credit for their HE degree. The remaining 20 percent were "not sure" if they had received any credit. All of these participants were in the first year of an under-graduate program. Some students felt that their VET studies had prepared them for HE and they enjoyed the opportunities presented. Others struggled with the workload, had difficulty finding a work-life balance, and found the emphasis on online learning in higher education problematic. Financial difficulties were also cited as a constraint. 


\section{CDU Focus Group}

The CDU focus group cohort was motivated to undertake vocational education for a number of reasons. Some students saw vocational education as a stepping stone to HE, others wanted to gain the skills and qualifications to be a "voice" in the community, and some students wanted a career path-way. As one student commented:

[I] ...had [a] lame job with minimum wage - moved from job to job - did not earn enough. I wanted to get a good paying job. Can't get ahead in life without a degree. VET is the first step in education. It's pointless in life earning the minimum wage.

Although the CDU students were highly motivated to complete their studies they faced a number of challenges. As the follow comment indicates, financial difficulties and a perceived lack of scholarships were common problems identified by the students:

[we] ...need more scholarships - particularly in first year. These scholarships are needed in first year not in third [year of a Degree]. I struggle financially. Not having any money I dropped out for 6 month - got a job but came back to study. I need to live, pay rent and buy food. I got a credit card to make ends meet but got into debt with the card. [My] ...Parents had to pay off the debt. [We] ... need accommodation scholarship in first year.

The cost and the availability of childcare was also another major issue students experienced:

A lack of childcare places at CDU - I have to go into Darwin each day for childcare - it's the only placement available ... JET ${ }^{3}$ cuts off without warning - and I am faced with a $\$ 6000$ childcare bill ... The cost of child care, fees [is prohibitive] ... The JET program does help but only for two years.

Students also expressed concerns about the lack of culturally appropriate and culturally safe space on campus. Their comments included, "We need to have culturally safe space and a sense of security...a communal room - other students have taken over the room." Students also commented on the campus accommodation:

Accommodation on campus is too noisy - too many parties. It is easier [financially] to live at CDU as living with others such as friends and family drains money but CDU is too noisy.

Whilst the students had encountered a number of challenges in their study they also commented on the opportunities and positive outcomes they had experienced. Employment opportunities, increased self-confidence, and increased English language competence were some of the reported outcomes. Students also commented favourably on the tutorial support they had received. As one student said, "Three quarters of the [Indigenous] students would not have got over the line without tutor assistance."

\section{BIITE Focus Group}

The BIITE focus group cohort had very different experiences to the CDU cohort. Their reported motivation to study included gaining competence in written and spoken English, to gain work related skills, to understand the world beyond their community, and to communicate more effectively with the non-indigenous community. The student's anecdotal comments indicate the range of reasons they were undertaking a VET program:

Come to learn more skills in writing and maths so as I can get a job in my community ... [I] Need an education to help me in my job ... [I] Need to communicate with white community ... To understand the world ... [I] have never been to school ... teachers help explain things.

\footnotetext{
${ }^{3}$ JET - Jobs, Education, and Training (JET) Child Care Fee Assistance provides extra help with the cost of approved child care for eligible parents undertaking activities such as job search, work, study, training, or undertaking rehabilitation to enter, or re-enter, the workforce as part of an Employment Pathway Plan or Participation Plan.
} 
The residential program the students were participating in had a number of perceived advantages and disadvantages. The Batchelor environment was generally regarded as conducive to study. Students regarded the campus and student accommodation as a culturally 'safe' place. A number of students indicated that the campus environment was also comparatively 'quiet'. The lack of distractions on campus was also perceived as an advantage. As one student commented, "My neighbourhood is very noisy so this environment is very quiet."

Students expressed satisfaction with a range of matters associated with their residential course. They commented favourably on the food, the lecturers, the library, and the opportunity to work with other students. The aspects of the program the students expressed dissatisfaction with included having to spend time away from the family and the community and having to forfeit pay to attend the course. As indicated by the following comments the comparative isolation from their family and community was a concern for a number of students, "When we come here a long time we worry about family ... Missing children ... Missing home ... don't like being away from my family."

Some students also felt linguistically isolated. The majority of students spoke a language other than English at home. However, on campus English and Creole was the only common language shared by students, tutors, and lecturers. Communicating in English or Creole 24 hours a day was difficult for some students. As one student commented, "[It is] ... hard having to speak in English or Creole all the time with other students - no one here speaks language."

The aspects of the course the students would like to see improved included tutorial support in their community, a designated place in their community to study, additional resources such as books and computers in their community, more countrymen and women in the course, and the opportunity to communicate in language with other students.

\section{CONCLUSION}

The pathways indigenous students take from post-compulsory education to paid employment are multiple and varied. These pathways are not necessarily linear or sequential. As evidenced in this report, indigenous people perceive the acquisition of employment related skills as a means to enhance their employment and career prospects, the opportunity to engage with further education and the broader community. Consequently, the vocational education and training sector has an important role in equipping indigenous students with the knowledge and skills required to participate in paid employment and the main stream economy. For indigenous people participation in vocational education and training can provide a pathway to employment, a career, re-employment, or higher education.

As indicated in this report, a significant number of indigenous people in the Northern Territory participate in vocational education and training. The means of engaging with vocational education includes, but is not restricted to residential programs, full time study, part time study, and the mainstream on-campus experience. Although the percentage of indigenous enrolments in vocational education at Charles Darwin University is relatively high in comparison to the national average, the pattern of indigenous enrolment, completion, and attrition is broadly consistent with national trends.

In the vocational education sector at Charles Darwin University, indigenous enrolments were characterised by the proportionally low number of enrolments in comparison to non-indigenous enrolments, a high concentration of male students, the relatively young age of the student cohort, a high concentration of students in Certificate I and II courses, and a small number of graduands at the Certificate IV and Diploma level. In comparison to the nonindigenous cohort, student retention and completion rates were also extremely low and attrition was high.

Despite the high rate of non-course completions, the interviewees experience the VET sector was generally positive. All interviewees perceived their VET study had provided them with an increased range of opportunities. Improved employment prospects, greater career opportunities, and increased work related responsibilities were commonly cited positive outcomes of the interviewees VET experience. Students also reported increased confidence, an increased proficiency in written and spoken English, increased educational opportunity, and an improved capacity to assist family, friends, and the community. 
Students living in urban and regional areas had relatively easy to access to vocational education and training. However, the lack of training facilities, resources, and tutors in the more remote areas of the Territory required students from these locations to temporarily relocate to Batchelor in order to undertake vocational education. Although students regarded the campus at Batchelor as a 'culturally safe' environment, the physical, social, and linguistic isolation associated with relocation was for a number of students, quite acute. The educational disadvantage associated with 'remoteness' was reflected in the comparatively low level of courses the students were undertaking, the nature of their courses, their proficiency in spoken and written English, and their comparatively high unemployment rate.

For the students who had completed a Certificate IV, the pathway from vocational education to higher education was a viable option. However, due to the low the pool of graduands at the Certificate IV, Diploma, and Advanced Diploma level, this pathway was under-utilised. The students who had progressed from vocational education to higher education at Charles Darwin University generally felt that their previous study was relevant. However, some students felt unprepared for the more academic environment of higher education. A number of students indicated they required more computer assistance, assistance with Learnline, the online learning platform, and information on available financial support. Financial constraints, a lack of available on-campus childcare, and a perceived lack of 'culturally safe' study space and accommodation were identified as significant issues for a number of students. These issues may be contributing to the high indigenous attrition rate that occurs in the first year of the under-graduate and second year of post graduate studies.

In the period 2000-2009, indigenous students represented less than 5 percent of the higher education cohort at CDU. However, the gap between indigenous and non-indigenous HE participation was most significant in the area of post graduate study where indigenous students represented less than 0.7 percent of the total post graduate enrolments.

Indigenous students utilised a variety of pathways to obtain admission into higher education at Charles Darwin University. The most frequent Basis of Admission (BOA) was previous higher education study, followed by alternative pathways (including "mature age," "Tertiary Enabling Program," and "other"), secondary education results, and vocational education studies. The higher education courses with relatively high indigenous enrolments were in the areas of nursing and education, followed by law, business, and behavioural studies. Indigenous employment prospects in the Territory, particularly in the areas of nursing and education are high and as a consequence, courses in these areas attract student enrolments.

Indigenous engagement with HE programs was characterised by a high attrition rate, a high rate of noncompletions, and a low graduation rate. In the period 2000-2009 approximately 25 percent of under-graduate and 46 percent of post graduate students completed their course. In terms of actual student numbers this equates to less than $80 \mathrm{HE}$ graduands per year.

Increasing indigenous retention, completion, and progression rates in both the VET and HE sector is crucial to closing the gap between indigenous and non indigenous education and employment outcomes. It is particularly important to increase the pool of potential graduands at the Certificate IV and Diploma level as these qualifications not only provide greater career opportunities but also a pathway to HE. Additional financial support, increased access to advice and information, employer support, and targeted academic assistance may also help stem the high attrition rates that occur in both the VET and HE sectors. Indigenous HE students in particular, require targeted assistance in their first year of study.

Due to the relatively small number of indigenous students participating in under-graduate and post-graduate programs, their visibility in these programs is low. The volume of students who transition from VET to HE is minimal and there is limited research on the role of dual sector universities in increasing indigenous access to education and improved employment outcomes. For many indigenous students, vocational education is a crucial pathway from post compulsory education to work. However, the pathways are constrained by physical, cultural, financial, and intuitional barriers that will require innovative solutions to overcome. As the Bradley (2008) review acknowledged, education can transform the lives of individuals and through them their communities. However, it will take a significant effort on behalf of all stakeholders to enable indigenous students to realise their personal and professional aspirations. 


\section{ACKNOWLEDGEMENT}

Funding for this project was provided by the Australian Government Department of Industry, Innovation, Science, Research, and Tertiary Education through the National VET Research Program managed by NCVER. The views and opinions expressed in this article are those of the author/project team and do not necessarily reflect the views of the Australian Government, State, and Territory Governments or NCVER.

\section{AUTHOR INFORMATION}

Dr. Susan Bandias is a Senior Lecturer in the School of Business at Charles Darwin University. She is a Fellow of the Australian Computer Society (ACS), and a Member of the Australian Institute of Management. Susan is currently Vice Chair of the NT Branch of the ACS, the Director of the national ACS Women's Board and a member of the ACS National Congress. Her particular areas of research interest include indigenous issues, telecommunications, and gender equity. Her recent publications have focused on the role of ICT in sustainable social and economic development and social media and social capital. Her publication record includes refereed journals, conference papers, professional publications, books, and multimedia. Susan has also contributed to public policy in the areas of ICT and sustainable development. E-mail: Susan.Bandias@cdu.edu.au (Corresponding author)

Don Fuller is the Professor of Governance at Charles Darwin University. He is a long term resident of the Northern Territory and had an extensive career in public service before moving to academia. His research interests are in the areas of economic development, indigenous issues, and governance. He has published extensively on matters concerning public policy, indigenous economic development, and governance. His publication record includes refereed journals, conference papers, professional publications, books, and book chapters. E-mail: Don $\underline{\text { Fuller@cdu.edu.au }}$

Professor Steven Larkin is a Kungarakany man from Darwin in the Northern Territory. Prior to 1995, Steve worked in urban, rural, and remote Aboriginal communities in health and community development programs whilst working with the Northern Territory government. In 1995, Professor Larkin was appointed by the Australian medical Associate (AMA) as their National Aboriginal Health Advisor. In 1997, Professor Larkin became the inaugural Chief Executive Officer for the National Aboriginal Controlled Health organisation (NACHHO). In 1999, Professor Larkin joined the Commonwealth Department of Health and Aged care as an Assistant Secretary in the Office of Aboriginal and Torres Strait Islander Health (OATSIH) where he managed the Social Health (including the implementation and management of the Bringing Them Home Program), Substance Misuse, Men's and Prison's health, Executive Policy as well as Research and data programs. In 2002, Professor Larkin managed the National Indigenous Employment program for a brief period before transferring to the Australian Institute of Aboriginal and Islander Studies (AIATSIS) as Deputy Principal. In 2004, Professor Larkin was appointed CEO of the institute. In 2009, Professor Larkin took up his current position of Pro Vice Chancellor - Indigenous Leadership with Charles Darwin University. E-mail: Steven.Larking@cdu.edu.au

\section{REFERENCES}

1. ABS (Australian Bureau of Statistics). (2002). Australian Social Trends 2002. Canberra: ABS.

2. ABS (Australian Bureau of Statistics). (2006). Population characteristics of Aboriginal and Torres Strait Islander Australians. Canberra: ABS.

3. Access Economics. (2008). Future demand for higher education. Canberra: Department of Education, Employment and Workplace Relations.

4. Alford, K., \& James, R. (2007). Pathways and barriers: Indigenous schooling and vocational education and training participation in the Goulburn Valley region. Adelaide: NCVER.

5. Asmar, C., Page, S., \& Radloff, A. (2011). Dispelling myths: Indigenous students' engagement with university. Adelaide: ACER. Retrieved October 2011 from http://www.acer.edu.au/documents/ aussereports/AUSSE_Research_Briefing_Vol10.pdf

6. Attorney General's Department. (2011). Closing the gap. The Prime Ministers Report 2011. Canberra: Commonwealth Government. 
7. Behrnedt, L., Larkin, S., Griew, R., \& Kelly, P. (2012). Review of higher education access and outcomes for Aboriginal and Torres Strait Islander people: Final Report July 2012. Canberra: Australian Government.

8. Bradley, D., Noonan, P., Nugent, H., \& Scales, B. (2008). Review of Australian higher education: Final report. Canberra: DEEWR.

9. Creswell, J., \& Tashakkori, A. (2008). Editorial: Mixed methodology across disciplines. Journal of Mixed Methods Research, 2(1), 3-6.

10. Curtis, D. (2008). VET pathways taken by school leavers. Australian Council for Educational Research, Victoria. Retrieved October 2011 from http://www.acer.edu.au/documents/LSAY_lsay52.pdf

11. Davidson, B., \& Jennett, C. (1994). Addressing disadvantage - A greater awareness of the causes of Indigenous Australians' Disadvantage. Canberra: Australian Government Publishing Service.

12. DEEWR (Department of Education, Employment and Workplace Relations). (2008). National report to parliament on Indigenous education and training, 2008. Canberra: DEEWR.

13. DEEWR (Department of Education, Employment and Workplace Relations). (2011a). Review of higher education access and outcomes for Aboriginal and Torres Strait Islander people. Canberra: DEEWR.

14. DEEWR (Department of Education, Employment and Workplace Relations). (2011b). Training. Canberra: DEEWR. Retrieved October 2011 from http://raining.gov.au/Search/SearchOrganisation?name=\&org SearchByNameSubmit=Search\&AdvancedSearch=\&JavaScriptEnabled=true\&registrationManagers=-99

15. DEEWR (Department of Education, Employment and Workplace Relations). (2012). Trainging.gov.au. Canberra: DEEWR. Retrieved October 2012 from http://training.gov.au/Reporting/ReportInfo?reportName $=$ RtoCount

16. DEST (Department of Education Science Training). (2006). National report to Parliament on indigenous education and training, 2004. Canberra: DEST.

17. Dockery, M., \& Milson, N. (2007). A review of indigenous employment programs. Adelaide: NCVER.

18. Encel, J. (2000). Indigenous participation in higher education. Canberra: Department of Education Training and Youth Affairs.

19. Gabb, R., Milne, L., \& Cao, L. (2006). Understanding attrition and improving transition. Melbourne: Victoria University. Retrieved October 2011 from http://tls.vu.edu.au/portal/site/research/ resources/Understanding\%20attrition.pdf

20. Giddy, K., Lopez, J., \& Redman, A. (2009). Brokering successful Aboriginal and Torres Strait Islander employment outcomes Common themes in good-practice models. Adelaide: NCVER.

21. Goulding, C. (1999). Grounded theory: Some reflections on paradigm, procedures and misconceptions. Wolverhampton: University of Wolverhampton.

22. Gray, M., Hunter, R., \& Schwab, R. (2000). Trends in Indigenous educational participation and attainment, 1986-96. Australian Journal of Education, 44(2), 101.

23. Greene, J. C. (2008). Is mixed methods social inquiry a distinctive methodology? Journal of Mixed Methods Research, 2(1), 7-22.

24. Harris, R., Raine, L., \& Sumner, R. (2005). Student traffic: Two-way movement between vocational education and training and higher education. Adelaide: Centre for Research in Education, Equity, and Work.

25. Indigenous Higher Education Advisory Council. (2006). Improving indigenous outcomes and enhancing indigenous culture and knowledge in Australian Higher Education. Canberra: IHEAC.

26. Indigenous Higher Education Advisory Council. (2008). Submission to the review of Australian higher education. Canberra. Retrieved October 2011 from http://www.deewr.gov.au/Indigenous/HigherEducation/Programs/IHEAC/Documents/HER.pdf

27. Klassen, A., Creswell, J., Plano Clark, V., Smith, K., \& Meissner, H. (2012). Best practices in mixed methods for quality of life research. Quality of Life Research, 21(3), 377-80.

28. Larkin, S. (2011). Aspiration leadership progress: Indigenous data sets. Darwin: Charles Darwin University.

29. MCEETYA (Ministerial Council on Education Employment Training and Youth Affairs). (2008). Australian directions in indigenous education 2005-2008. Victoria: MCTEETYA. Retrieved October 2011 from http://www.mceetya.edu.au/verve/_resources/exploringmultiplepathways_file.pdf 
30. Moodie, G. (2010). Change and transformation in student transfer from Australina vocational to higher education. Australian Vocational Education and Training Research Association (AVETRA) Conference, Surfers Paradise, Queensland. Retrieved October 2011 from http://avetra.org.au/wp-content/uploads/ 2010/04/44.00-Gavin-Moodie.pdf

31. NCVER (National Centre for Vocational Education and Reseaerch). (2004). Australian vocational education and training statistics Indigenous Australians' training experiences 2004. Adelaide: NCVER. Retrieved October 2011 from http://www.voced.edu.au/content/ngv25019

32. NCVER (National Centre for Vocational Education and Reseaerch). (2009). Indigenous students. Adelaide: NCVER. Retrieved October 2011 from http://www.ncver.edu.au/publications/2156.html

33. NCVER (National Centre for Vocational Education and Reseaerch). (2010). Students and courses:Australian vocational education \& training statistics. Adelaide: NCVER. Retrieved October 2011 from http://www.voced.edu.au/content/ngv47262

34. Nguyen, N. (2010). Early post-school outcomes of Indigenous youth: The role of literacy and numeracy, Adelaide: NCVER.

35. O'Callaghan, K. (2005). Indigenous vocational education and training. At a glance. Adelaide: NCVER.

36. Onwuegbuzie, A., \& Combs, J. (2011). Data analysis in mixed research: A primer. International Journal of Education, 3(1), 1-25.

37. Onwuegbuzie, A., Turner, L., \& Johnson, R. (2007). Toward a definition of mixed methods research. Journal of Mixed Methods Research, 1(2), 112-33.

38. Patton, M. (1980). Qualitative evaluation methods. Beverly Hills: Sage Publications.

39. Pole, K. (2007). Mixed method designs: A review of strategies for blending quantitative and qualitative methodologies. Mid-Western Educational Researcher, 20(4), 35-8.

40. Productivity Commission. (2003). Overcoming indigenous disadvantage; Key indicators 2003. Melbourne: Productivity Commission. Retrieved October 2011 from http://www.pc.gov.au/_data/assets/pdf_file/ 0005/61277/keyindicators2003.pdf

41. Productivity Commission. (2011). Overcoming indigenous disadvantage. Key indicators 2011. Melbourne: Productivity Commission. Retrieved October 2011 from http://www.pc.gov.au/gsp/reports/ indigenous/?a=111609

42. Ramsey, E., Tranter, D., Kain, M., \& Sumner, R. (1997). Cross sectorial linkages: A case study. Canberra: DEETYA. Retrieved October 2011 from http://www.dest.gov.au/archive/highered/eippubs/eip9713/front.htm\#execsum

43. Rossman, G., \& Wilson, B. (1985). Numbers and words: Combining quantitative and qualitative methods in a single large-scale evaluation study. Evaluation Review, 9, 627-43.

44. Salehi, K., \& Golafshani, N. (2010). Using mixed methods in research studies: An opportunity with its challenges. International Journal of Multiple Research Approaches, 4(3), 186-91.

45. Sieber, S. (1973). The integration of fieldwork and survey methods. American Journal of Sociology, 73, 1335-59.

46. Stringfield, S., Stipanovic, N., Withington, C., Drew, S., Hammond, C., Mobley, C., \& Sharp, J. (2012). A mixed methods sampling methodology for a multisite case study. Journal of Mixed Methods Research, $6(1), 34-54$.

47. University of Ballarat \& Swinburne University of Technology. (2010). Dual Sector University Cohesion A discussion paper. Melbourne, Victoria: Academic Research Centre. 


\section{NOTES}

